\title{
LETTERS
}

\section{Good things come in threes (and sometimes fours): Update on renin-angiotensin- aldosterone system inhibitors and COVID-19}

Since the publication of our article in CMAJ, ${ }^{1}$ there have been substantial developments in the literature regarding the role of renin-angiotensin-aldosterone system (RAAS) inhibitors in patients with coronavirus disease 2019 (COVID-19). We wish to summarize them here to support our recommendations on prescribing practices for these drugs.

Three large observational studies of more than 20000 patients with COVID-19 found no association between the use of RAAS inhibitors and increased risk of infection, development of severe disease or death. ${ }^{2-4}$ The 3 studies used different methodological approaches, and all came to similar conclusions.

A different cohort study of 18472 patients who were tested for severe acute respiratory syndrome coronavirus 2 (SARS-CoV-2) also found no association between RAAS inhibitor use and testing positive for COVID19. However, a secondary analysis of 1735 patients in the study with confirmed COVID-19 showed an increased risk of severe disease requiring admission to the intensive care unit in patients using RAAS inhibitors. ${ }^{5}$

All observational studies are at risk of unmeasured confounding. However, according to the results across these studies, RAAS inhibitors are unlikely to cause harm in patients with COVID-19.

In our original article, we reinforced recommendations from multiple professional societies that "the totality of current clinical and experimental evidence for RAAS inhibitors to facilitate infection by SARS-CoV-2 or increase the risk of harm in patients with COVID-19 is insufficient to suggest altering current use." ${ }^{1}$ We continue to support this view. Patients prescribed RAAS inhibitors should remain on them during the COVID-19 pandemic, pending release of high-quality and replicable data to the contrary.

\section{Kieran L. Quinn MD MSc}

Clinical associate, Department of

Medicine, University of Toronto; Division of General Internal Medicine and Geriatrics, Sinai Health System; Institute of Health Policy, Management and Evaluation, University of Toronto, Toronto, Ont.

\section{Michael Fralick MD PhD}

Assistant professor, Department of Medicine, University of Toronto; Division of General Internal Medicine and Geriatrics, Sinai Health System, Toronto, Ont.

\section{Jonathan S. Zipursky MD}

Clinical associate, Department of Medicine and Institute of Health Policy, Management and Evaluation, University of Toronto; Division of Clinical Pharmacology and Toxicology, Sunnybrook Health Sciences Centre, Toronto, Ont.

\section{Nathan M. Stall MD}

Clinical associate, Department of Medicine, University of Toronto; Division of General Internal Medicine and Geriatrics, Sinai Health System; Institute of Health Policy, Management and Evaluation, University of Toronto, Toronto, Ont.

Cite as: CMAJ 2020 June 1;192:E611. doi: $10.1503 / \mathrm{cmaj} .75720$

\section{References}

1. Quinn KL, Fralick M, Zipursky JS, et al. Reninangiotensin-aldosterone system inhibitors and COVID-19. CMAJ 2020;192:E553-4.

2. Reynolds HR, Adhikari S, Pulgarin C, et al. Reninangiotensin-aldosterone system inhibitors and risk of COVID-19. N Engl J Med 2020 May 1 [Epub ahead of print]. doi: 10.1056/NEJMoa2008975.

3. Mehra MR, Desai SS, Kuy S, et al. Cardiovascular disease, drug therapy, and mortality in COVID19. N Engl J Med 2020 May 1 [Epub ahead of print]. doi: 10.1056/NEJMoa2007621.

4. Mancia G, Rea F, Ludergnani M, et al. Reninangiotensin-aldosterone system blockers and the risk of COVID-19. N Engl J Med 2020 May 1 [Epub ahead of print]. doi: 10.1056/NEJMoa2006923.

5. Mehta N, Kalra A, Nowacki AS, et al. Association of use of angiotensin-converting enzyme inhibitors and angiotensin II receptor blockers with testing positive for coronavirus disease 2019 (COVID-19). JAMA Cardiol 2020 May 5 [Epub ahead of print]. doi: 10.1001/jamacardio.2020.1855.

Competing interests: None declared. 